\title{
TEACHER MIGRATION AND THE QUALITY OF BASIC EDUCATION IN THE UPPER WEST REGION OF GHANA
}

\author{
JAHA RAZAK IMORO \\ Dept of Sociology \\ University of Cape Coast \\ Cape Coast, Ghana \\ Email:jaha792001@yahoomail.com
}

COLLINS AHORLU

Noguchi Memorial Institute for Medical Research

University of Ghana, Accra, Ghana

Email: cahorlu@noguchi.mim.com

\author{
ERIC KOKA \\ Dept of Sociology \\ University of Cape Coast \\ Cape Coast, Ghana \\ Email:erickoka2000@yahoomail.com
}

\begin{abstract}
The Wa West District of the Upper West Region is an important sending area for teacher migrants to the Brong Ahafo Region, both in Ghana. This paper discusses the reasons for the out-migration of teachers and the effects on the quality of basic education in the Wa West District. The discussion focuses on the characteristics of the teacher migrants, reasons for outmigration and the performance of sending schools as a result of the out-migration. The goal is to expose some of the reasons that account for poor quality education in the Upper West Region while attempting to suggest remedies to this problem. To be able to do this a survey was conducted using questionnaire and interviews as main instruments. The survey revealed that economic push factors such as inadequate motivation for teachers in the sending District and the lack of alternative employment opportunities were key factors for teacher migration. The push conditions were found to result in the poor performance of pupils at the primary and junior secondary school levels in sending district. Consequently, it was concluded that improvements in the socio-economic and infrastructure of the sending district, which would aid in bridging the development gap between the two regions, would help in reducing teacher migration and improve the quality of basic education in the Wa West District.
\end{abstract}

KEY WORDS: Teacher Migration, Socio-Economic Forces, Quality Education, Development Gaps, Educational Parity

\section{INTRODUCTION}

The governments of Ghana have continued to affirm their commitment to the achievement of the Millennium Development Goals (MDGs) by the year 2015. The attainment of universal primary education, which is an important part of the MDGs, is a priority in Ghana's development efforts. The education sector ministry, in line with ongoing poverty reduction and socioeconomic growth priorities, has outlined in its Education Strategic Plan areas which are geared 
towards the achievement of the MDG on universal primary education. These areas include equitable access to education, quality education at all levels, educational management, science and technology. One of the policy goals under quality education is to improve the quality of teaching and learning for enhanced pupil and student achievement (MOESS, 2004).

The need for quality education cannot therefore be underestimated. The desire of the nation to achieve a middle-income status by the year 2015 will greatly depend on the human resource capacity of the nation. Therefore, the developmental efforts of the nation can better be propelled if its human resource is well developed starting with the provision of quality basic education in preparation for higher attainments. Education is the principal instrument for the development of skills required by the economy and also for improving the managerial performance of the labour force (Little, 1980). Basic education serves as the bedrock, if the capacity of the nation is to be enhanced. This means that the ability to provide quality education at the basic level will impact on the drive towards a quality human resource base.

This analysis in premised on the backdrop that if ongoing efforts at enhancing human resource quality, starting with the improvement of the quality of basic education, are to materialize, then what happens to areas in the Upper West Region, like others, where teacher migration is high needs prompt attention. The movement of teachers in search for better opportunities leaves the classrooms empty and thus impede teaching and learning in the schools. Indiscriminate teacher movements create gaps and result in uneven educational delivery. McKinnon (2003) explains that "if we want to build stronger wealthier communities, if we want to combat illness and poverty, if we want fairer and more equal societies then education is the only way forward."

The Upper West Region has been identified as the poorest region in the country (GLSS, 2000). It lags behind other regions in its progress in education, health and infrastructure resulting in high levels of poverty. The incidence of poverty in the Region was 88.4\% in 1991/1992 against the national average of $51.7 \%$ and $84.0 \%$ in $1998 / 1999$ against the national average of $39.5 \%$ and $87.9 \%$ in 2005/2006 against the national average of $28.5 \%$ (Ghana statistical Service, 2007). This trend of poverty is an indication that majority of the people in the region are poor. It also shows that the level of poverty, which has risen from $46.7 \%$ in $1991 / 1992$ to $54.6 \%$ in $2005 / 2006$, is unduly high. The Upper West Region, compared to other regions of Ghana, has consistently carried the largest part of the burden of poverty. Again about $82.5 \%$ of the Upper West Region is rural (GSS, 2002; Fobih, Koomson, \& Akyeampong, 1999).

On teacher quality, a 2002 study revealed that only $50.9 \%$ of basic school teachers at post nationwide were trained but in the case of the Upper West Region the rate was lower at $20.1 \%$ (International Workshop on Migration, 2005). Since, only trained teachers can take transfer, further losses are registered through out-migration. The persistent out-migration of teachers has tended to draw the region's clock of progress backwards and cast into doubt the desire of the Region to solve its poverty problem through education. Additionally, the area is among regions that register high teacher-pupil ratios; above the national average. The pupil teacher ratios for the three northern regions and particularly Upper West Region have remained high and above the national average since 2001/2002. See Table 1 below for details.

Table 1: Pupil/Teacher Ratio in Public Primary School in three Northern Regions

\begin{tabular}{|l|l|l|l|l|}
\hline \multicolumn{5}{|c|}{ Pupil/Teacher Ratio In Public Primary Schools } \\
\hline REGION & $\mathbf{2 0 0 1 / 2 0 0 2}$ & $\mathbf{2 0 0 2} / \mathbf{2 0 0 3}$ & $\mathbf{2 0 0 3 / 2 0 0 4}$ & $\mathbf{2 0 0 5 / 2 0 0 6}$ \\
\hline Northern & 36.4 & 34.2 & 38.6 & 35 \\
\hline Upper East & 52.7 & 49.8 & 58.9 & 45 \\
\hline Upper West & 38.7 & 41.8 & 46.2 & 35 \\
\hline NATIONAL & $\mathbf{3 1 . 9}$ & $\mathbf{3 2 . 2}$ & $\mathbf{3 4}$ & $\mathbf{3 3 . 1}$ \\
\hline
\end{tabular}


Source: Education Strategic Plan (ESP) 2005.

Table 1 above indicates that there are regional variations in pupil teacher ratios (PTRs) within the three northern regions with the Upper West Region recording disproportionately high rates. The pupil teacher ratios (PTRs) for Upper West exceed the national averages from 2001 to 2006, though it looks better than the Upper East Region. Though it is admissible that pupil teacher ratios are not sole indicators of educational quality, it gives indication to the number of pupils per teacher in the class with implications for time on contact, number and types of class assignments and special needs targeting. Classroom and instructional management is known to be adversely affected in large classes compared to smaller classes. It is on the basis of this that teacher-pupil ratio has been given prominence in this analysis. The issue of teacher-pupil ratio has greater impetus against the backdrop of low teacher qualification. In this case many of them are untrained. The low level of trained teachers raises concerns regarding the ability of the existing teachers to manage the large class sizes. Table 2 below shows the pupil teacher ratios in the various regions and the trained and untrained teacher ratio for the country.

Table 2: Distribution of Trained Teachers in Public Primary Schools in Ghana

\begin{tabular}{|l|l|l|l|}
\hline Region & $\begin{array}{l}\text { Average Pupil-Teacher } \\
\text { Ratio }\end{array}$ & $\begin{array}{l}\text { Average Trained } \\
\text { Teacher-Pupil Ratio }\end{array}$ & $\begin{array}{l}\text { Trained and } \\
\text { Untrained Teachers- } \\
\text { Pupil Ratio }\end{array}$ \\
\hline Ashanti & 35 & 50 & 27 \\
\hline Brong Ahafo & 32 & 41 & 25 \\
\hline Central & 36 & 65 & 28 \\
\hline Eastern & 30 & 39 & 24 \\
\hline Greater Accra & 47 & 89 & 70 \\
\hline Northern & 33 & 54 & 21 \\
\hline Upper-East & 48 & 64 & 31 \\
\hline Upper-West & 39 & 56 & 26 \\
\hline Volta & 28 & 32 & 22 \\
\hline Western & 34 & 67 & $\mathbf{3 0 0}$ \\
\hline Total & $\mathbf{3 6 1}$ & $\mathbf{5 5 5}$ & $\mathbf{3 0}$ \\
\hline National Average & $\mathbf{3 6}$ & $\mathbf{5 6}$ & \\
\hline
\end{tabular}

Source: Policy Research, Monitoring and Evaluation Unit, 2008.

National Pupil Teacher Ratios (PTRs), however, had large disparities in class sizes, with some urban primary schools having classes as large as 48 children, while many rural schools have classes of less than 30 (Policy Research, Monitoring and Evaluation Unit, 2008).This puts into question the quality that is delivered. Again the steady increase in the pupil teacher ratios requires corresponding increases in not only teacher supply and retention but also in the quality of teachers. This is especially so for rural areas such as the Wa West District where educational resources as scare and teachers must of necessity improvise in order to deliver lessons. Table 2 above shows that in 2007, teacher supply in the Upper West Region met the national average of 56. (The average Trained Teacher-Pupil Ratio is defined as Total Enrolment/ Total number of Trained Teachers). However, the question that remains is whether 
all the teachers supplied for the period actually stayed in classrooms in the Region in general and in the Wa West District in particular.

In view of the above, this paper looks at the effects of teacher out-migration on the quality of basic education in the Wa West District. Much of the research into this area of study (migration) has tended to focus on rural-urban migration with emphasis on agricultural labour migrants and to some extent general labour which requires minimal specializations. Some research in this direction include: research by Carolien Primavera (2005) on the "Effects of out-migration on the Sustainability of Agriculture in the Upper West Region." Kees Van der Geest (2004) also did a research on rural migration, environment and livelihoods in Ghana. That study traced the linkage between migration, livelihood, environment and family network. Another research on migration from the Upper West to Brong Ahafo Region was conducted by Gariba in 2002. This analysis, takes a different focus, with an emphasis on rural migration and on non-agricultural skilled labour with specific reference to the education sector.

\section{THE STUDY AREA}

The Wa West District is one of eight districts in the Upper West Region with a population of 9,996 (Population and Housing Census, 2000). The District is located in the north western part of the Region. It stretches from longitude $40^{\circ} \mathrm{N}$ to $245^{\circ}$ and from latitude $9 " \mathrm{~W}$ to $32^{\circ} \mathrm{W}$, thus covering an area of approximately 5,899.3 square kilometres. To the South, North-West and East, it has a common boundary with the Northern Region, Nadowli District and Wa Municipal respectively, and to the West with Burkina Faso (Ghanadistricts.com). The other districts of the Region are Nadowli, Jirapa/Lambusie, Lawra, Sissala East, Sissala West, Wa East and Wa Municipal. The Wa West District is a relatively new District, which was created in the year 2000.

The Wa West District is made up of culturally comparable ethnic groups comprising the Dagara, Dagaba, Wala, Wiili and Birifor as well as the non-Dagare-speaking Lobi. The Birifor occupy a slightly wider area compared to the rest and therefore could constitute the majority. These groups are very similar, ethnically and culturally, as well as linguistically (they all speak the closely related dialects of Dagare, except the Lobi, who speak Lobiri, an unrelated language) (Vercelli, 2006). These groups are similar enough to be regarded as one ethnic group. The majority of the people in the District are farmers and they cultivate crops such as millet, groundnuts, beans, soybeans and maize. The staple diet for the people is TZ meaning tuozaafi a Hausa word (Locally called saa). A growing tourist attraction for the district is the hippopotamus sanctuary in Wechiau, which is currently receiving national attention (Ghanadistricts.com).

\section{THEORETICAL AND CONTEXTUAL PERSPECTIVES}

The issue of migration has been discussed from different theoretical perspectives depending on the type of migration in question. For the purposes of this analysis, of which out-migration and related concerns have been at issue, push and pull factors have been of interest. It draws heavily on a classic push and pull model by Lee (1966).

\section{Push and Pull Theory of Migration}

The most widely discussed migration model, the push-pull factor model, proposed by Lee as far back as 1966, is adopted for the purpose of this analysis. This model postulates that decisions to migrate are related to two types of factors: push factors and pull factors. Push factors are those factors in a present (sending) destination that cause people to leave while pull factors are factors in an external (receiving) destination that cause people to leave their present (sending) destination. 
In the context of the Upper West Region, the push factors are the dry climatic conditions of the area, soil infertility, low incomes, lack of alternative employment opportunities and poor educational facilities. Northern Ghana is known for its erratic rainfall pattern which is fast turning it into a desert, a situation which is associated with loss of soil fertility (Andrew, Shepherd and Gyimah-Boadi, 2005). The impact on productivity tends to cause farmers to move in search of alternatives. In the Wa West and northern Ghana, this has taken the form of movement down south to the middle belt where environmental conditions are better and favour farming all the year round. The weather situation serves as an incentive for the farmers who migrate to the middle belt of the country. In this case the push (dry weather conditions) and pull (all year farming) factors are at play.

In a similar vein, the Upper West Region lags behind other regions in terms of educational infrastructure, better schools, and good road network. These serve as disincentives for teacher retention in the Region as a whole but particularly so for rural districts such as the Wa West. The largely rural nature of Wa West (at 82.5\%), where there are hardly any higher education preparation opportunities, has been perceived by teachers as an area where they cannot easily further their education. The teachers believe that their continuous stay in that rural area will impede their progress as such they seek better opportunities elsewhere where they can teach and further their education (Fobih, Koomson \& Akyeampong, 1999). The primary pull factors to other regions outside Upper West Region include proximity to Distance Education Centres, cheaper food sources, opportunities for extra incomes, peer exchanges and learning material as well as better educational and health facilities. The secondary ones include electricity supply, communication facilities, road networks, good drinking water and sewerage system (Gariba, 2002). Both the primary and secondary drivers comprise push and pull factors. Thus, with regard to the teacher migration situation of Wa West, like the rest of the Region, it is the desire to get ahead and not the desire to escape an unpleasant situation that has motivated the movements.

Adepoju (2003) classifies the patterns of migration within and from West Africa in three epochs - the historical, pre-independence and post-independence era. The focus of the classification is on intra-West African migration, intra-African migration or brain circulation. Anarfi (1982) says migration movements have been a feature of Africa in the past and is one of its most important demographical features today. Migration within West Africa, and between that region and the rest of the continent, dates back to time immemorial (Arhin 1978, in Anarfi, 1982). The transSaharan caravan routes are among the earliest evidence of major interactions between West and North Africa for trading in goods and exchange of scholars.

In the case of Ghana, the patterns of internal migration in the country as a whole and the Upper West Region in particular are varied. The interplay of push and pull factor but also short and long term needs push people to move in different or similar but also particular or general directions.

First, throughout Ghana there is a flow from rural areas to urban and semi-urban areas. Secondly, there is a flow from northern Ghana to southern Ghana and to the food crop but also commercial crop frontier of the middle belt. Thirdly, within northern Ghana, there is a flow from the densely populated Upper East Region and the western part of the Upper West Region to the sparsely populated parts of the Northern Region and the eastern part of the Upper West Region (Van Der Guest, 2000). In the northern Ghanaian context, attempts to explain this migratory trend have always centred on theories of over population, land shortage (in terms of land infertility), taxation (in the case of the colonial period) lack of resource (both human and natural) and "bright lights" which actually compelled northerners to migrate to the south in search of wage labour (Gariba, 2002). Much of the movement, which is seasonal, has also been attributed to off-farm season needs. 
Thirdly, within southern Ghana, there is a flow towards the cocoa frontier in the Western Region and the food crop frontier in the Afram Plains (Twum-Baah et al, 1995). The characteristics of internal migrants give the impression of a predominantly young migrant population. In Ghana, Caldwell (1969) estimates that the highest propensity to migrate occurs in the 15-19 year age category. Primavera (2005) revealed that out-migration can have two different effects on the sustainability of agriculture and population in the Upper West Region. One major effect is the demographic changes in the Region. Since the out-migration is dominated by men, women are left behind and they have to take on additional farm work responsibilities in weeding, planting and harvesting, among others. The literature on predisposing factors of internal migration suggests that poorer villages (usually remote) tend to be the "sending" areas and urbanized locations or richer villages (usually well connected) tend to be the "receiving" areas (Dev \& Evenson, 2003). It is evident, therefore, that the climatic conditions in an area are crucial factors in determining the migration phenomenon.

Nabila (1974) argues that the reason for the migration of northerners to the south is the overpopulation on a limited land resource. Therefore out-migration provides an escape-valve from the stringent survival system. Voigt-Graf (2003) who conducted a research on the outmigration of teachers in Fiji confirmed that many teachers have joined the internal flow to urban areas in Fiji for many reasons. In the rural areas, access to government services and transport and communications infrastructure is restricted. The Ministry of Education also faces difficulties in providing, administering and monitoring its services. Additionally, many rural schools in Fiji are poorly equipped and school buildings are not in a particularly good state. Teachers therefore migrate to the urban areas to better their lives and take advantage of the offerings of urban living.

\section{General Migration in the Upper West Region}

According to Goldscheider (1971) migration is defined as any permanent change in residence; it involves the detachment from the organization of activities at one place and the movement of the total round of activities to another. The researcher adopted the definition from Goldscheider for the purpose of this analysis. This is because teachers who migrate move their total round of activities as well as change in their residence from one region to the other. However, the situation in the Wa West District is the case of internal out-migration which occurs when a registered resident member migrates out from his or her current location to another location that is still inside the demographic surveillance area. (Resource Kit for Demographic Surveillance Systems, www.google.com).

The researcher defines internal out migration as a temporary, semi-permanent or permanent change of residence to a place outside the native region but within the country. The study, specifically examines rural-urban migration. Intra-regional migration refers to population movement between localities within an administrative region, while inter-regional migration which describes the movement of people between different regions of the country (Population Census, 2000). The table below describes the intra and inter-migration indicators among the three northern regions and the Brong Ahafo region.

Table 3: Intra and Inter-Migration Indicators

\begin{tabular}{|l|l|l|}
\hline Region & Intra-migration in Percentage & Inter-migration percentage \\
\hline Upper West & 10.0 & 5.8 \\
\hline Upper East & 2.4 & 5.4 \\
\hline Northern & 8.4 & 6.0 \\
\hline
\end{tabular}




\begin{tabular}{|l|l|l|}
\hline Brong Ahafo & 7.6 & 20.2 \\
\hline National & 9.9 & 17.5 \\
\hline
\end{tabular}

Source: Population Census, 2000

Table 3 above indicates that the Upper West has a relatively high intra-migration rate (10.0) which implies that people move to different parts of the Region in significant numbers. The movement is usually from rural to business and commercial centres such as Wa; the regional capital. Movement is also to other areas within the region where agriculture is quite profitable such as the Sissala area, where there are relatively vast lands for farm cultivation. Again observing the inter-regional migration indicators, it could be deduced that the Upper West Region experiences a minimal inter-regional migration compared to other regions such as the Brong Ahafo and Northern regions. However, the rate of out-migration which refers to the temporary, semi-permanent or permanent change of residence to a place outside the native region but within the country for the Upper West region is high. At the same time, the rate of inmigration which is the proportion of residents in the Upper West Region who were born in other regions besides the Upper West Region is relatively low.

The analysis in this paper is informed by an investigation on the out-migration of skilled labour (teachers) from the Wa West District to the Brong Ahafo Region. The figures for out-migration according to the 2000 Population Census indicate that five regions including the Upper West Region are relatively large sending areas, in the sense that about a fourth of the population of these regions live in other regions: Upper West (31\%), Volta (28\%), Central (27\%), Eastern (25\%) and Upper East (24\%), while the remaining five regions have less than 15 per cent living of their populations in other regions (GSS, 2002).This is further illustrated in Table 4 below.

Table 4: In-Migration, Out-migration, Net Migration and Net Migration rates.

\begin{tabular}{|l|l|l|l|l|}
\hline Region & In-migration & Out-migration & Net-Migration & Net-Migration Rate \\
\hline Upper West & 36,221 & 227,874 & $-191,653$ & -332.4 \\
\hline Upper East & 54,129 & 255,661 & $-201,532$ & -219.0 \\
\hline Northern & 117,557 & 256,279 & $-139,216$ & -76.5 \\
\hline Brong Ahafo & 371,557 & 207,808 & $+163,749$ & +90.2 \\
\hline
\end{tabular}

Source: Ghana Statistical Service (GSS) (2002): 2000 Population and Housing Census.

The net migration rate, which is the net effect of in-migration and out-migration across regions, shows that the Upper West Region has a net loss of 332 per 1000 population (GSS, 2002).This further implies that the Upper West Region is one of the regions in the country that loses a high number of people to other regions and especially so to the Brong Ahafo Region. The Brong Ahafo Region is the nearest and has a conducive atmosphere and high capacity for lucrative socio-economic activities such as agriculture (Gariba, 2002). Therefore, the net loss of persons, which involves mostly the youth, includes teachers, nurses and unskilled seasonal migrants for agriculture purposes. For the purposes of this analysis, teacher migration is of interest.

\section{Teacher Out-Migration in the Upper West Region}

\section{Problems of Teachers}

There are many instances of teacher shortage and absenteeism in rural communities that have been attributed to the harsh living and working conditions (Hedges, 2003). Hedges conclusion can be attributed to the situation in the Wa West District and the Upper West Region, where 
teacher out-migration has tended to be high. The Upper West Region suffers from an acute shortage of teachers in rural areas leading to a situation where many schools are simply not productive. For instance, according to the Policy Research, Monitoring and Evaluation Unit of the Ghana Education Service, after the close of teacher positing for the year 2006, the Region still had 38 vacancies unfilled. The question is, if vacancies exist after postings and if those who are at post also decide to migrate out of the region leaving the classrooms empty, what becomes of the spaces? and what does that mean in relation to teaching and learning?.

The challenges facing teachers who teach in rural areas of Ghana include poor school infrastructure and accommodation. The Upper West Region presents a particularly difficult challenge for teachers, especially newly trained teachers. For example, teachers posted to the rural parts of the Upper West Region have to learn how to live within the extended family household compound. Rural community housing requires communal living arrangements that teachers unaccustomed to the situation find especially difficult. Besides, teachers face problems of unsafe drinking water, lack of electricity, poor health facilities, limited transportation to neighbouring towns and lack of personal development opportunities (Action Aid Survey Report, 2000).

One particular difficulty of providing basic education for children in the rural areas of the Upper West Region is the nature of community settlements. These tend to be small and widely scattered. Finding appropriate locations for building schools to service reasonable population becomes a real problem. This has led to the building of some primary schools in obscure places with no community identity (Fobih et al, 1999). Therefore, many communities are not close enough to a formal school, which means that pupils have to walk long distances to reach them. According to the Core Welfare Indicators Report of 1998, the Upper West Region has the highest percentage of children walking over 30 minutes to school each day. Distance to school is ranked as one of the major reasons for many children not attending school in the Upper West Region.

\section{Basic Education in Ghana and the Upper West Region}

Until the mid-70s, education in Ghana was one of the most developed in Africa but the quality of education declined afterwards. The proportion of public resources spent on education fell from $6.4 \%$ of GPD in 1976 to $1.4 \%$ by 1983 (MOESS, 2004). The construction, completion and maintenance of educational facilities grounded to a halt; foreign exchange for the purchase of textbooks, library materials, scientific equipments and other essential instructional materials were scarcely available. There was a mass exodus of trained teachers, especially the more qualified ones to Nigeria and Botswana where they sought greener pastures (Graham \& Hormeku, 2005). This resulted in a situation, in 1987/88, where more than half of public primary school teachers were untrained.

By the end of the 1980s, an estimated two thirds of Ghana's 15 million people were functionally illiterate (MOESS, 2004). According to the Core Welfare indicators (2003) about 50\% of the population aged 15 years (adult literacy) and above could read and write forming $53.4 \%$ which is an indication that majority of the population could be described as literates meanwhile in the case of the Upper West Region only $24.4 \%$ of the population 15 years and above could read and write; a demonstration that the majority of the population are illiterates. However, on youth literacy, the population between ages 15 to 24 years comprised $68.7 \%$ of those who could read and write; a manifestation of good quality education among the youth in the country. Yet, in the case of the Upper West Region the rate was $46.2 \%$ of the same population, which is not only far below the national average but also explains in part the poor quality education in the region.

\section{METHODOLOGY}

\section{Target Population and sample}


The population for the study for this analysis constituted teachers in the Basic and Junior Secondary School levels in the Wa West District and teachers who had migrated to the Brong Ahafo Region. They comprise all teachers in the basic and junior secondary schools who had taught in the Upper West Region but had ever migrated to the Brong Ahafo Region. They include both natives and non-natives of the Upper West Region.

There are a total of 83 basic schools in the Wa West District. This is made up of 51 primary schools and 32 junior secondary schools. Purposive sampling (Non-probability) and Stratified sampling techniques (Probability) were used for sample selection. There were 344 teachers for the basic schools in the district (GES -Wa, 2006). The researcher selected 120 of these teachers. This was arrived at first by stratifying the teachers according to their ranks. The researcher did the stratification using the list of all the basic schools in the District with the commensurate number of teachers in each school. The teacher qualifications by ranks in the District are shown in Table 5 below.

\section{Table 5: Teacher Qualification by rank in the WA West District}

\begin{tabular}{|l|l|l|}
\hline Ranks & Total & $\begin{array}{l}\text { Percentage } \\
\text { (\%) }\end{array}$ \\
\hline Certificate “A” Four years & 21 & $6 \%$ \\
\hline Certificate “A” Three years & 89 & $26 \%$ \\
\hline Basic Education Diploma (BED) & 4 & $1 \%$ \\
\hline SSSCE & 194 & $56 \%$ \\
\hline Technical /Vocational & 24 & $7 \%$ \\
\hline GCE “A” Level & 3 & 0.9 \\
\hline GCE “O” Level & 4 & $1 \%$ \\
\hline National Service Personnel & 4 & $1 \%$ \\
\hline Arabic Teachers (GCE “O” Level) & 1 & $0.3 \%$ \\
\hline Total & $\mathbf{3 4 4}$ & $\mathbf{1 0 0}$ \\
\hline
\end{tabular}

Source: Wa West District Assembly, 2006

After the teachers were stratified by ranks the researcher employed a purposive sampling technique in selecting individual teachers. Using the list of all the schools in the District with the commensurate number of teachers in each school, the researcher selected individual teachers to serve as the sample participants. This was done using purposive sampling to include the head teacher and two other teachers from each school depending on the number of teachers on staff at the selected school. This was done until a total of 120 teachers answered the questionnaire. This method also covered (42) schools in the District.

The rationale behind this method was to get teachers who understood the teaching problems in the schools. Moreover, the researcher wanted teachers who could really understand the questionnaire. The researcher was also interested in making sure that as many teachers as possible responded to the questionnaire. The researcher focused on the total number of teachers who had left the Region from 2000 to 2007. It was revealed that between 2000 and 2007, a total of 596 teachers had migrated to other regions of the country (Wa Regional Education Directorate, 2007). Out of this number, 255 chose the Brong Ahafo Region while 200 
went to the Ashanti Region; both within the middle belt. This therefore supports statistical records that more than two fifths (44.2\%) of the northerners born in the Brong Ahafo Region were from Upper West (Ghana Statistical Service, 2000). The remaining 141 were sparsely distributed among the other regions of the country.

\section{Methods of Data Collection}

Interviews were conducted with selected officials from both the District and the Regional Education Office in the Upper West Region. The officials of the District Education Office were interviewed to find out what incentive packages or motivations were available for teachers in the District. On the other hand, officials of the Regional Education Office were interviewed to find out why teachers leave the Region as well as their preferred destinations. In all, four (4) officials were interviewed ( 2 district officials and two regional officials).

In the Wa West District, quantitative data were also collected. Self-administered questionnaire were given to heads of basic schools (primary and junior secondary schools) and two teachers each from selected basic schools. The questionnaire method was used because respondents were literates. It also allowed respondents ample time to understand the questions before answering them although this may also lead to bias as respondents may discuss the questions with other colleagues. The questionnaire sought to find out the performance of the pupils over a six year period and whether the inadequacy or absence of teachers has changed performance both at the primary and junior secondary school levels. The researcher used the Basic Education Certificate Examination (BECE) and the Pupil Teacher Ratio (PTR) to determine the performance of pupils.

\section{CHARACTERISTICS OF MIGRANTS AND REASONS FOR OUT-MIGRATION.}

\section{Age Distribution of Teacher Migrants}

In the Brong Ahafo Region, fifty (50) copies of the questionnaire were administered over a three week period between $1^{\text {st }}$ to the $21^{\text {st }}$ of March 2007. This was done to determine the most migratory category.

Table 6: Age Distribution of Teacher Migrants

\begin{tabular}{|l|l|l|}
\hline Age Categories & Frequency & Percentage \\
\hline $20-26$ & 9 & 18 \\
\hline $27-33$ & 16 & 32 \\
\hline $34-40$ & 11 & 22 \\
\hline Above 40 & 14 & 28 \\
\hline Total & 50 & 100 \\
\hline
\end{tabular}

Source: Field work, 2007

The study revealed that age group that migrates most is the 27-33 age-group. A look at the data from the two research areas revealed that it was the youth that actually migrated most leaving behind the relatively old teachers. It was also found that young teachers migrated because of their burning desire to improve themselves. Also, their decision to migrate was less likely to be constrained by their families and family-related attachments. The age structure of the Wa West District shows that majority of the population are below 15 years implying that the active population which is 15-29 and 30-44 are the minority (Ghanadistricts.com). This could be due 
partly to out-migration, which left the District with more dependent population who could not engage in any active economy activities. This confirmed existing literature on the characteristics of internal migrants (Hans, 2000; Harteveld, 2005; Tacoli, 2001; Hare, 1999). In a detailed research on the topic "The Effects of Out-Migration on the sustainability of Agriculture in the Upper West Region," Primavera (2004) reported similar nature of migrants from the Region. In that study, Primavera established that it was mostly young men between the ages of 17 to 30 and sometimes younger than 17 years who moved out of the Region.

\section{Qualifications of Teachers Migrants}

The question of teacher qualifications was necessitated by the fact that the researcher wanted to confirm which category of teachers by qualification were migrating out of the District. A number of studies have shown that there is a positive relationship between higher education qualifications and migration (Corbett, 2004; White et al, 2002; Morissette, 2000). From Canada, Corbett (2004) observed that people who possess higher levels of formal education were more prone or more able to leave rural communities. Similarly, those who stayed, without higher education credentials, do not reap significant economic benefits from their schooling. This implies that the higher one's education the higher the tendency for the person to leave the rural community since chances of the person benefiting from the higher education in terms of jobs and status may be high.

The situation involving teachers from the Upper West Region as shown by Table 7 below does confirm the assertion that higher educational credentials determine, to a large extent, the rate of out-migration from the region. This is because teachers with certificate " $\mathrm{A}$ " are the majority on the migration stream but again those with the highest qualification (first degree), though few, are equally migrating on a higher rate. Nonetheless, this has consequences for quality education especially at the basic level. Therefore, for these teachers, who form the few educated people in the District, their out-migration affects not just the quality of basic education but also the general development of the District.

Table 7: Qualifications of Teacher Migrants

\begin{tabular}{|l|l|l|}
\hline Qualification & Frequency & Percentage \\
\hline First Degree & 12 & 24 \\
\hline Teachers Certificate "A" & 27 & 54 \\
\hline Diploma in Education & 11 & 22 \\
\hline Total & 50 & 100 \\
\hline
\end{tabular}

Source: Field work, 2007

Corbett (2004) established that education was powerfully associated with out-migration only when that migration took the individual outside a 50-kilometre circle.

Also, Bollman (1999) reports from rural Canada that the economic "returns" on education were significantly less in rural compared to urban communities in terms of educational attainment. This implies that persons with higher education qualifications who stay in rural, compared to those in urban areas, gain less from their education as they are not able to optimise their benefits. This contributes to explaining why individuals with higher education in the rural communities migrate into the urban areas. Hence, persons with higher education have tended to maximize their benefits by migrating to urban areas. This explains the inadequacy, and to some extent, the non-existence of first degree holding teachers in the Wa West district. This affects 
education in the rural area since such people could serve as rural change agents who can drive major changes to rural development.

In the case of Wa West, highly qualified teachers do not seem to benefit from their qualifications as since basic socio-economic conditions are inadequate and in some cases not available.

Therefore, to be able to maximize their benefits in education the most appropriate thing to do is to move out of the District and their most convenient destination has been the Brong Ahafo Region. Anarfi et al (2001) suggest that one out of every four returning migrants had university education. This further emphasizes the fact that the relationship between education and outmigration is not only limited to internal migration but also international migration.

\section{Economic Push Factors}

This research work was aimed at finding out why teachers were leaving the Wa West District for the Brong Ahafo region and for that matter the reasons that motivating teachers to migrate to the Brong Ahafo Region. The results as gathered during the research are discussed below.

\section{Low level of motivation}

To find out whether lack of incentives was a cause of out-migration of teachers from the Wa West District, the researcher asked respondents whether the District was lacking teachers. The result obtained was overwhelming with $83 \%$ answering in the affirmative, while $17 \%$ thought that the District did not lack teachers. A question on which aspect of the teaching was a worry to teachers produced the result in the Table 5 below.

\section{Table 8: Aspects of teaching that was a worry to Teacher Migrants}

\begin{tabular}{|l|l|l|}
\hline Teaching Problem & Frequency & Percentage \\
\hline Lack of Text Books & 12 & 24 \\
\hline Lack of Incentives & 26 & 52 \\
\hline No Class Rooms & 12 & 24 \\
\hline Total & $\mathbf{5 0}$ & $\mathbf{1 0 0}$ \\
\hline
\end{tabular}

Source: Field work, 2007

Incentives are known to be some form of motivation to get a job done. Work motivation refers to the psychological processes that influence individual behaviour with respect to the attainment of workplace goals and tasks. The salary of workers including teachers are generally inadequate and for teachers in the rural areas there is a heavier burden of acquiring good food, accommodation, health, transport, potable water and other social amenities. The salaries of teachers do not cover basic household survival needs, let alone enable teachers enjoy a reasonable standard of living (Hedges, 2003). While salaries continue to depreciate the cost of living continues to escalate. This makes rural teachers live in difficulty. The salary scales of basic school teachers are flat with very small increment over long times usually per annum. Even where there are increments they do not meet the basic survival needs of these rural teachers. Below is an expenditure table of a rural teacher as gathered by the researcher in the course of the field work. 
Table 9: Expenditure Pattern of a Certificate " $A$ " Teacher in the Wa West District

\begin{tabular}{|c|c|c|}
\hline Items & Cost in Cedis & Market Price \\
\hline \multicolumn{3}{|l|}{$\underline{\text { Provisions }}$} \\
\hline Tea & $\mathrm{GH} \pitchfork 0.50$ & $\mathrm{GH} \$ 1.00$ \\
\hline Milk & $\mathrm{GH} \pitchfork 1.20$ & $\mathrm{GH} \$ 1.20$ \\
\hline Sugar & $\mathrm{GH} \$ 0.50$ & $\mathrm{GH} \$ 1.00$ \\
\hline $\begin{array}{l}\text { Kulekule (A substance made from groundnut } \\
\text { paste which is eaten ) }\end{array}$ & $\mathrm{GH} \$ 1.00$ & GP\$0. 70 \\
\hline \multicolumn{3}{|l|}{ Food Items } \\
\hline Kerosene Stove & $\mathrm{GH} \$ 3.50$ & $\mathrm{GH} \$ 4.00$ \\
\hline Kerosene & GH2.50 (a month) & $\mathrm{GH} \pitchfork 3.00$ \\
\hline Rice ( 1 Bowl ) & $\mathrm{GH} \$ 1.80$ & $\mathrm{GH} \pitchfork 2.00$ \\
\hline Frytol (1 litre ) & $\mathrm{GH} \pitchfork 1.20$ & $\mathrm{GH} \pitchfork 2.00$ \\
\hline Maggie & $\mathrm{GH} \$ 0.70$ & $\mathrm{GH} \$ 0.70$ \\
\hline Onions & GH\$0. 40 (Weekly) & $\mathrm{GH} \$ 0.60$ \\
\hline Ketaboys (1 Bowl) & GH\$2.40(Weekly) & $\mathrm{GH} \$ 2.40$ \\
\hline \multicolumn{3}{|l|}{$\underline{\text { Others }}$} \\
\hline Wireless & $\mathrm{GH} \$ 5.00$ & $\mathrm{GH} \$ 5.00$ \\
\hline Dry cells & $\mathrm{GH} \$ 0.50$ & $\mathrm{GH} \$ 1.00$ \\
\hline Transportation(Weekly) & $\mathrm{GH} \$ 3.00$ & $\mathrm{GH} \$ 3.00$ \\
\hline Camp- bed & $\mathrm{GH} \$ 12.00$ & $\mathrm{GH} \$ 12.00$ \\
\hline Mosquito net & $\mathrm{GH} \pitchfork 2.00$ & $\mathrm{GH} \pitchfork 2.50$ \\
\hline Bicycle & $\mathrm{GH} \$ 14.00$ & $\mathrm{GH} \$ 15.00$ \\
\hline Torch light & $\mathrm{GH} \$ 3.00$ & $\mathrm{GH} \$ 2.00$ \\
\hline Funeral & $\mathrm{GH} \$ 0.50$ & $\mathrm{GH} \$ 0.50$ \\
\hline Miscellaneous & $\mathrm{GH} \$ 2.00$ & $\mathrm{GH} \$ 2.00$ \\
\hline Total Expenditure & GH $\$ 64.00$ & GH 461.60 \\
\hline \multicolumn{3}{|l|}{ Income/Allowance: } \\
\hline (A)Salary (Level 10 ) : & GH $\$ 150.00$ & \\
\hline (B)Alternative employment ( Barber) & GH $\$ 12.00$ & \\
\hline Total Income: $(A+B)$ & GHథ 214.00 & \\
\hline
\end{tabular}

Source: Field work, 2007 
Table 9 above is illustrative of the inadequacy of the salaries of rural teachers. Though some items such as bicycles, wireless sets, camp-bed and mosquito nets are not daily expenditure, Table 9 gives an idea of the living costs of rural teachers.

The inadequate salary means that teachers must do something in addition to teaching to meet survival requirements. Teachers in the rural areas take to either trading or farming and in the absence of these out-migration becomes a viable alternative as revealed in this research. Therefore, in the case of teachers in the Wa West District, the absence of incentives makes the teaching profession unattractive and therefore makes teachers to explore opportunities where they can maximize their potentials and more importantly gain access to these incentives. The motivation packages mentioned by the respondents were varied including means of transport (motor cycles), promotions for rural teachers and rural teaching allowances. Other incentives mentioned were proper housing, potable water, good road network, and information and health facilities. This confirms findings from Fiji (Voigt-Graf, 2003) which shows that teachers in rural areas in Fiji did not have access to government services, transport and communications infrastructure. There were also difficulties in providing, administering and monitoring teaching services due to the inaccessibility of rural areas. Teachers therefore migrate to urban areas in order to better their lives and take advantage of urban life. However, many teachers, according to Voigt-Graf (2003) showed concern about poor educational opportunities for their children.

Another demonstration of the teacher out-migration phenomenon arising from the lack of incentive was revealed in an Action Aid Ghana study on the Upper West Region which showed that teachers face problems of unsafe drinking water, lack of electricity, poor health facilities, limited transport to neighbouring towns and lack of personal development opportunities (Action Aid Ghana, 2000).

\section{Unavailability of other Income generating activities in the District}

The researcher wanted to know whether teachers were engaged in farming, livestock rearing, or trading before they migrated out of the Region. However, it was evident that some teachers in the Brong Ahafo Region left the Wa West District because they were not engaged in any other income generating activities. This shows in the responses of teachers in the Brong Ahafo as depicted in Table 10 below.

Table 10: Respondent views on involvement in other income generating activities

\begin{tabular}{|l|l|l|}
\hline Opinion & Frequency & Percentage \\
\hline Yes & 16 & 32 \\
\hline No & 34 & 68 \\
\hline Total & $\mathbf{5 0}$ & $\mathbf{1 0 0}$ \\
\hline
\end{tabular}

Source: Field work, 2007

The unavailability of income generating activities can be partly attributed to the geography of the Wa West area. The general nature of the soils, coupled with the traditional land use practices and type of rainfall, tend to have adverse effects on crop production. Traditional land use practices such as bush burning before tilling the land and other human activities which cause land degradation affect crop production in the District. These human activities include heavily cultivated lands, overgrazing and firewood collection. This does not make farming profitable. This has also accounted for many seasonal migrants living to the Brong Ahafo Region. The crops that are supported by such lateritic soils in the District include millet, guinea corn, groundnuts, maize, bambara beans and ordinary beans. Therefore, villages closer to the Black Volta can have some bumper harvest compared to villages far away from the Black Volta. 
Crop yields greatly depend on the amount of rainfall per annum. Given that rainfall in the Upper West Region is generally less than $1050 \mathrm{~mm}$ per annum, low yields are often expected from crops cultivated (Ghanadistricts.com). See Table 11 below.

Table 11: Regional crop production, 2000 (Yield: tonnes/ha. Production 000 tonnes)

\begin{tabular}{|c|c|c|c|c|c|c|c|c|}
\hline Region & \multicolumn{2}{|l|}{ Maize } & \multicolumn{2}{|l|}{ Rice } & \multicolumn{2}{|c|}{ Cassava } & \multicolumn{2}{|l|}{ Yam } \\
\hline & Yield & $\begin{array}{l}\text { Producti } \\
\text { on }\end{array}$ & Yield & $\begin{array}{l}\text { Product } \\
\text { ion }\end{array}$ & Yield & $\begin{array}{l}\text { Product } \\
\text { ion }\end{array}$ & Yield & $\begin{array}{l}\text { Product } \\
\text { ion }\end{array}$ \\
\hline $\begin{array}{l}\text { Brong } \\
\text { Ahafo }\end{array}$ & 1.75 & 166 & 0.61 & 3 & 13.46 & 1702 & 14.96 & 1432 \\
\hline Northern & 0.80 & 79 & 2.40 & 73 & 6.50 & 211 & 10.0 & 518 \\
\hline Upper East & 1.56 & 16 & 2.08 & 65 & - & - & - & - \\
\hline Upper West & 1.62 & 57 & 2.26 & 9 & - & - & 11.63 & 263 \\
\hline
\end{tabular}

Source: Statistics, Research and Information Directorate (SRID), Ministry of Food \& Agriculture, February 2001.

Table 12: Regional Crop Production, 2001(Yield: tonnes/ha. Production 000 tonnes)

\begin{tabular}{|l|l|l|l|l|l|l|l|l|}
\hline Region & \multicolumn{2}{|c|}{ Maize } & \multicolumn{2}{c|}{ Rice } & \multicolumn{2}{c|}{ Cassava } & \multicolumn{2}{c|}{ Yam } \\
\hline Yield & $\begin{array}{l}\text { Product } \\
\text { ion }\end{array}$ & Yield & $\begin{array}{l}\text { Producti } \\
\text { on }\end{array}$ & Yield & $\begin{array}{l}\text { Product } \\
\text { ion }\end{array}$ & Yield & $\begin{array}{l}\text { Producti } \\
\text { on }\end{array}$ \\
\hline $\begin{array}{l}\text { Brong } \\
\text { Ahafo }\end{array}$ & 1.69 & 168 & 0.61 & 3 & 14.10 & 1873 & 14.96 & 1475 \\
\hline Northern & 0.67 & 70 & 1.85 & 63 & 7.35 & 382 & 8.87 & 621 \\
\hline Upper East & 1.50 & 15 & 1.8 & 72 & - & - & - & - \\
\hline Upper West & 1.40 & 51 & 2.50 & 10 & - & - & 11.87 & 283 \\
\hline
\end{tabular}

Source: Statistics, Research and Information Directorate (SRID), Ministry of Food \& Agriculture, February 2001.

The figures and production yields demonstrate that farming in the Upper West Region and for that matter Wa West District is not often profitable. Above all, there has been a general fall in the production yields of various crops over a two year period as a result of low rainfall. This is a strong push factor that can drive teachers, who would otherwise have stayed in the area, away and to places where farming is more lucrative. Teachers who would want to engage in supplementary employment avenues such farming cannot do so because farming is not profitable due to the low rainfall resulting in low yields. For example, comparing the yield and production levels of Upper West Region and Brong Ahafo Region, it could be realized that the latter is better in terms of maize, cassava and yam productions compared to the former.

The situation of poor yields is further manifested by an insightful research done by Gariba in 2002 in the Upper West Region. In that study, the most striking reasons for migrating out were ecological, economic, and social. Ecologically, the survey revealed that Upper West Region, which lies within the Guinea Savannah belt, has one of the most degraded environments in the country. Rainfall patterns in the Region are characterized not only by their seasonality but also by their variability and unreliability. Although, the rainfall varies between 950 and $1050 \mathrm{~mm}$ per annum, occurring between May and October, effective rainfall is far less because this amount may occur within a few months. The net result is soil erosion and depletion of soil fertility, poor harvest and therefore the inability of people to have good harvest. The exodus and existence of migrant families in the south could be attributed to the lower rainfall, savannah vegetation and remote and inaccessible location of much of the north. This, coupled with the lack of alternative 
sources of income in the region, has made many people including teachers to seek greener pastures and the place for them is the Brong Ahafo Region.

\section{Performance of Schools in the Wa West District}

This part of the analysis examines the performance of schools in the District. The Basic Education Certificate Examination results of the Junior Secondary Schools were accessed during the period of migration. This is to find out the effects of out-migration on the Basic Education Certificate Examination results of the basic schools in the Wa West District during the period. In addition, the Pupil Teacher Ratios of the primary schools were also accessed to determine the availability of qualified teachers in the District.

\section{Performance of Junior Secondary Schools in the District}

The researcher accessed the Basic Education Certificate Examination (BECE) performance in the District for the year 2005/2006. There are a total of thirty-two Junior Secondary Schools in the District. However, there was difficulty in accessing the performance of each of the thirty two Junior Secondary Schools. This was because some head teachers did not have adequate data on the BECE results. Some head teachers were also just posted to some of the Junior Secondary Schools which did not have head teachers before then. Junior Secondary Schools without head teachers let their students take the BECE together with students of the nearest school that had a head master or mistress. Therefore, data on the junior secondary schools did not necessarily show the actual student population of that particular school. The researcher realizing this accessed the BECE performance for the whole district for year 2005/2006.The analytical results are displayed in Table 13 below.

Table 13: BECE Result for Wa West District for $2005 / 2006$

\begin{tabular}{|l|l|}
\hline DESCRIPTION & NUMBERS \\
\hline $\begin{array}{l}\text { Number of Candidates registered for B.E.C.E in } \\
\text { the District }\end{array}$ & 451 \\
\hline Number Passed & 209 \\
\hline Number Failed & 242 \\
\hline Percentage passed & $46 \%$ \\
\hline Number Placed & 166 \\
\hline Number not Placed & 43 \\
\hline
\end{tabular}

Source: District Education Office Wa West

The results show an abysmal performance in the Basic Education Certificate Examination for the District. This is because out of a total of 451 candidates only $46 \%$ passed. This was made up of 209 passes and 242 failures. However, the placement also gives an idea as to the nature of the performance, whether the passes were good or not. This is because out of the 209 that passed only 166 got placement in the secondary schools in the region. The District has only one Senior Secondary School and can therefore absorb more but because of the nationally computerized placement system most of those without good passes were left out of the national system. The factors that account for this abysmal performance have been important to this analysis; which has been interested in the effects of teacher out-migration of education quality, with performance as a variable. 


\section{Performance of Primary Schools}

The pupil teacher ratios were used to access the performance of primary schools in the District. The pupil teacher ratio shows the number of pupils per teacher in the classroom. The researcher used this to determine the adequacy of teacher enrolment of the District. The number of pupils per teacher also contributes to the performance of pupils. This is because the fewer the number of pupils to a teacher the better the level of interaction between teacher and pupils. Therefore, the researcher used the District level pupil teacher ratio as basis for accessing the performance. Available data showed that the national pupil teacher ratio is 1:35, but in the Wa West District the ratio was 1:41 as at 2007. This is far above the national average which gives the indication that there are more pupils to a teacher in the District.

The availability of learning materials can also be a problem due to large class sizes. The physical strain of the teacher can also be a problem in this circumstance. There are a total of 51 primary schools in the District. The researcher compared the pupil teacher ratios of the schools to find out which schools have pupil teacher ratios more than the District average as against those schools that have met the district average. Out of the total of 51 primary schools nine (9) have met the District level pupil teacher ratio while the remaining (42) have pupil teacher ratios above that of the District average (41). This situation has consequences for pupil performance.

Schools with pupil teacher ratios lower than the District average could be better in terms of performance compared to schools which have Pupil Teacher ratios above the district average. Meanwhile, the researcher is cautious of the fact that pupil teacher ratios could also explain the level of enrolment in the District. The pupil teacher ratios could imply poor or low enrolment rate in some schools.

\section{The Shutting Down of Schools}

Another important objective of the research was to find out whether some schools in the District had been closed down and the reasons cited for the closures. The researcher therefore asked teachers (respondents) in the Wa West district whether some schools have been closed in the past. The result was overwhelming because majority (69\%) answered in the affirmative. The reasons cited for the closure of these schools ranged from distance from home to school which made pupils to have a lackadaisical attitude toward school in general. The lack of teachers was also indicated as one of the major reasons why schools were closed down. Another important reason mentioned was the poor nature of the roads which make schools inaccessible especially during the rainy season. Table 16 below displays the reasons respondents cited for the closure of these schools in the District.

Table 16: Reasons for the Closure of Schools

\begin{tabular}{|l|l|l|}
\hline Reason & Frequency & Percentage \\
\hline Lack of Teachers & 64 & 53 \\
\hline Inaccessibility of road network. & 33 & 28 \\
\hline Distance from town to school & 23 & 19 \\
\hline Total & 120 & 100 \\
\hline
\end{tabular}

Source: Field work 2007

Table 16 indicates that the majority (53\%) associated the closure of some schools to lack of teachers .This adds to the already existing evidence in the research that the District lacks teachers. The lack of teachers in the District has resulted in the closure of schools .This certainly 
has consequences for the quality of education in the District. The inaccessibility of roads in the District which received 28\% of respondents views also contributed to the closure of some schools. This is partly due to the rural nature of the District which makes it inaccessible. This also makes the District unattractive to teachers especially the young ones.

The distance from home to school was also cited by some respondents as a cause of the closure of some schools. Twenty three respondents (19\%) associated distance from home to school as the cause of the closure. This is consistent with much of the literature on the cause of poor quality education in the rural areas. One such research was carried out by (Fobih et al, 1999) which revealed that finding appropriate locations for building schools to service reasonable size of rural populations becomes a real problem. This has led to some primary schools being built in the most obscure places with no community identity. Therefore, many communities are not close enough to a formal school which means that pupils have to walk long distances to reach them. The Wa West District is basically made up of feeder roads with some of them inaccessible not only for the teachers who are posted to the district but also to rural residents.

\section{CONCLUSION}

The analysis above demonstrates that teacher out-migration remains a significant challenge to educational quality promotion in the Wa West District in particular and the Upper West Region in general. The high levels of teacher movement, which has been motivated by various push and pull factors, have resulted in deserted and poorly staffed classrooms and schools where academic activity in poorly delivered. Factors stemming largely from poor opportunities for higher qualification pursuits, but also lack of incentives and alternate incomes as well as poor infrastructure and services delivery compel teachers to move out of the Region in search of better opportunities. This situation has resulted in high teacher-pupil ratio with the attendant problems of inadequate delivery. These have in turn led to poor performance of pupils at nationally competitive examinations.

\section{RECOMMENDATIONS}

The following recommendations, if positively considered and implemented by governments and other stake holders would solve the problem of teacher out-migration and poor school performance in the Wa West district and the Upper West Region as whole.

\section{* Provision of adequate motivation to Teachers in the Rural Areas}

The provision of adequate incentives in the Wa West District is paramount if this out-migration should be minimized. Therefore adequate incentives should be provided to teachers in the District to motivate them well enough to stay in the rural area and deliver quality teaching to the deprived rural pupils.

\section{* Extra Allowances for Rural Teachers}

To make teachers stay in the District, the authorities should design schemes that provide extra allowances for rural teachers. This will give them extra income compared with urban teachers. This will also them enable cope better with rural life.

\section{Teachers should be sponsored to further their Educational Ambitions}

Another important recommendation is the sponsorship of teachers in the district to further their educational ambitions. Out-migration is seen as a way to which they can exploit chances in other areas financially to further their education. Thus, Brong Ahafo region becomes an option. It is recommended that teachers in the district should be sponsored to further their education. 


\section{REFERENCES}

Action Aid Ghana (2000). Action Aid Pilot Education Survey: Draft Ghana Report. Ghana: Accra (unpublished).

Adepoju, A. (2003). "Patterns of Migration in West Africa." In Takyiwaa Manuh, Ed (2005) At Home in the World? International Migration and Development in Contemporary Ghana and West Africa. (pp.25-54) Accra: Sub-Saharan Publishers.

Adepoju, A. (2003). Migration in West Africa Development Vol.46,No.3:37-41.

Anarfi, J.K. (2001). "Migration, Return and Impact in Ghana: A Comparative Study of Skilled and Unskilled Transnational Migrants." In Takyiwaa Manuh, Ed. (2005). At Home in the World? International Migration and Development in Contemporary Ghana and West Africa (pp.205-226). Accra: Sub-Saharan Publishers

Anarfi, J.K. (1982). International Labour Migration in West Africa: A Case of the Ghanaian. ISSER: Ghana Universities Press.

Akyeampong, Fobih and Koomson. (1999). Ghana Primary Schools Development Final Evaluation of Project Performance. Accra: Ministry of Education.

Arhin, K. (1978). “Gold Mining and Trading Among the Ashanti of Ghana.” \ournal des Africaniles, Vol.1: (pp. 48)

Aryee, A.F, J.S. Nabila and Twum-Baah, K.A. (1995). Motivation in the Migration Decision Process. Paper presented at the Seminar on Social Science Research, University of Ghana, and Legon (unpublished).

Bollman, R. D. (1999). "Human Capital and Rural Development:. What are the Linkages?" In N. Walford, J.C. Everett and D.E. Napton (Eds) Reshaping the Country side: Perception and Process of Rural Change. New York: CABI Publishing

Caldwell, J. (1969). African Rural-Urban Migration: The Movement to Ghana's Towns. Canberra: Australian University Press.

Carmen, Voigt-Graf (2003). "Fijian Teachers on the Move: Causes, Implication and Policies." Asia Pacific Viewpoint, Vol. 44, No.2:163-175.

De Haan, A. (2000). "Livelihoods and Poverty: The Role of Migration - A Critical Review of the Migration Literature.” \ournal of Development Studies Vol.36, No. 2: 1-47.

Dev, S. M. and Evenson, R.E. (2003). Rural Development in India: Agriculture, Non-farm and Migration. Mimeo.

Gariba, B. Abdul-Korah. (2002) “Where is not home?” Dagaaba Migrants in the Brong Ahafo Region 1980 to the Present. Oxford, UK: Oxford University Press

Ghana Statistical Service (2007). Trends and Patterns of Poverty in Ghana 1992-2000. Accra: Statistical Service.

Ghana Statistical Service (2004). Core Welfare Indicators Survey 1998. Accra: Statistical Service. 
Ghana Statistical Service (2004). Core Welfare Indicators Survey 2003. Accra: Statistical Service

Ghana Statistical Service, Health Research Unit and ORC Macro (2003). Ghana Service Provision Assessment Survey 2002 August. Accra: Statistical Service

Ghana Statistical Service (2000). Ghana Living Standard Survey (GLSS3). Accra: Statistical Service

Ghana Statistical Service (2000) .Ghana Living Standard Survey (GLSS4). Accra: Statistical Service

Ghana Statistical Service (2000). Population and Housing Census, Summary Report of Final Results. Accra: Statistical Service.

Ghana Statistical Service (1999). Participatory Poverty Assessment (1999). Accra: Statistical Service

Ghana Education Service, Upper West Regional Education Directorate (2007) Educational Statistics. Statistics Department Upper West Region: Wa, Ghana: Regional Education Directorate (unpublished).

Ghana Education Service Wa Regional Education Directorate (2007). Transfers and Postings of Teachers . Upper West Region: Wa Regional Education Directorate (unpublished).

Ghana Education Service Wa West District Education Directorate (2006). Annual Report on Enrolment and Teacher Supply in the District. Upper West Region: Wa West District Education Directorate (unpublished).

Goldscheider, C. (1971). Population, Modernization and Social Structure Boston: Little Brow

Graham, Y. and Hormeku, T. (2005) Basic Education: 1999-1994 retrieved from http://www.socialwatch.org DA: 5 ${ }^{\text {th }}$ April 2006

Gyimah-Boadi, E. A. and Shepherd, E. (2005). Bridging the North South Divide in Ghana Accra: Ghana Universities Press.

Hare, D. (1999). "Push versus Pull Factors in Migration Outflows and Returns: Determinants of Migration Status and Spell Duration among China's Rural Population.” \ournal of Development Studies 35(3): 45-72.

Hedges, J. (2002). "The Importance of Posting and Interaction with the Education Bureaucracy in becoming a Teacher in Ghana." (Researching Teacher Education: The Multisite Teacher Education Report.) International Journal of Educational Development, Vol. 22 (pp 3-4).

Institute for Social and Statistical and Economic Research (2005). International Workshop on Migration. Report on the International Workshop for Migration of the Highly-Skilled. University of Ghana: ISSER.

Kees Van der Geest. (2004). Rural Migration Environment and Development retrieved from htt://users.fmg.uva.nl/kgeest. DA: $5^{\text {th }}$ April 2006

Lee, E.S. (1966). “A Theory of Migration.” Demography Vol. 3, No.1: 47-57. 
McKinnon, D. (2003). Speech at $15^{\text {th }}$ Conference of Commonwealth Education Ministers. United Kingdom: Edinburgh.

Michael, Corbett (2004) Rural Education and Out-Migration: The Case of a Coastal Community. Unpublished Doctoral Dissertation, University of British Columbia

Ministry of Food \& Agriculture (2001). Statistics, Research and Information Directorate (SRID) Accra: Ministry of Food \& Agriculture.

Morissette, R. (2000). Rural Youth: Stayers, Leavers and Return Migrants. Canada: Statistics Canada.

Nabila, J.S. (1974). The Migration of the Frafra of Northern Ghana: A Case Study Of Cyclical Labour Migration in West Africa. Michigan State University East Lasing, Unpublished PHD dissertation.

Primavera, Carolien. (2005). The Effects of Out-Migration on the Sustainability agriculture in the Upper West Region. Amsterdam: University of Amsterdam.

Reed, White et al. (2002). An Event History Analysis of Internal Migration in Ghana: Determinants of Interregional Mobility among Residents of Coastal Central Region. U.S.A.: Population Studies and Training Centre Brown University.

Republic of Ghana (2005). Education Sector Strategic Plan (2000-2005)Accra: Ministry of Education.

Republic of Ghana (2008). Policy Research, Monitoring and Evaluation Accra: Ministry of Education.

Republic of Ghana (2004). Education Sector Performance Report: Meeting the Challenges of Education in the twenty first century. A Report of the President's Committee on review of education reforms in Ghana. Accra: Ministry of Education.

Resource Kit for Demographic Surveillance System (2006). www.google.com. (DA: ....) Sjaastad, L.A (1962). "The Costs and Returns of Human Migration." The Journal of Political Economy, Vol. 70:25-40.

Tacoli, C. (2001). Urbanization and Migration in Sub-Saharan Africa: Changing Patterns and Trends Leiden: Brill

Vercelli, B. Michael (2006). Performance Practice of the Dagara-Birifor Gyil Tradition through the Analysis of the Bewaa and Daarkpen Repertoire. Tucson: University of Arizona.

Wemmy, Harteveld (2004). Rural-to-Rural Migration and Female Livelihood: The Case of Dagara Women in Ghana. Amsterdam: University of Amsterdam._www.Ghanadistricts.com 